\title{
A comparison between academic achievement and language aptitude among pre-service language teachers
}

\author{
Kübra Askak \\ Feryal Cubukcu \\ Dokuz Eylul University \\ Izmir, Turquía
}

\begin{abstract}
The main purpose of this research is to investigate whether there is a correlation between university pre-service language teachers' language aptitude and their English achievement levels. The sample of the study determined by the stratified sampling method consists of 72 pre-service language teachers who are selected from 1st, 2nd, 3rd and 4th year pre-service language teachers at Language Teaching Department. In this study, the data were collected through "Verbal Aptitude Test" modified from the psychometric success site. In this program, the Spearman Correlation Coefficient analysis was used to elicit the correlation of pre-service language teachers' language aptitude with their English achievement levels. The results indicated that while there is a moderate relation of pre-service language teachers' English achievement levels with their rote learning ability and grammatical sensitivity there is a weak relation of phonetic coding ability with language aptitude. Additionally, a slight correlation between pre-service language teachers' inductive learning ability and their achievement levels is found. All in all, even if the dimensions of language aptitude test pointed to some degree of correlation between the components of language aptitude and English achievement level, the overall results of the language aptitude test indicated that there is a weak correlation between preservice language teachers' language aptitude and achievement levels. However, the fact that pre-service language teachers have low language aptitude scores does not guarantee they will be less successful in language learning.
\end{abstract}

Key words: language aptitude; language learning; achievement level. 


\section{Resumen \\ Interfaz entre aptitudes y niveles de logro del lenguaje de los profesores de idiomas practicantes}

El objetivo principal de este trabajo es investigar si existe una correlación entre las aptitudes lingüísticas de los profesores universitarios de idiomas en prácticas y sus niveles de rendimiento en inglés. La muestra del estudio determinada por el método de muestreo estratificado consta de 72 profesores de idiomas en prácticas que son seleccionados entre los profesores de idiomas de $1^{\underline{0}}, 2^{\underline{0}}, 3^{\underline{0}}$ y $4^{\underline{0}}$ años del Departamento de enseñanza de idiomas. En este estudio, los datos se recopilaron a través de la "Prueba de Aptitud Verbal" modificada del sitio de éxito psicométrico. En este programa, el análisis del coeficiente de correlación de Spearman se usó para obtener la correlación de la aptitud lingüística de los profesores de idiomas practicantes con sus niveles de inglés. Los resultados indicaron que si bien existe una relación moderada entre los niveles de rendimiento de inglés de los profesores de idiomas practicantes con su capacidad de aprendizaje de memoria y la sensibilidad gramatical, existe una relación débil entre la capacidad de codificación fonética y la aptitud lingüística. Además, se encuentra una ligera correlación entre la capacidad de aprendizaje inductivo de los profesores de idiomas en prácticas y sus niveles de rendimiento. En general, incluso si las dimensiones de la prueba de aptitud lingüística apuntaban a un cierto grado de correlación entre los componentes de la aptitud lingüística y el nivel de rendimiento en inglés, los resultados generales de la prueba

144 de aptitud lingüística indicaron que existe una correlación débil entre la aptitud lingüística de los profesores practicantes y los niveles de rendimiento. Sin embargo, el hecho de que los profesores de idiomas en práctica docente previa tengan bajos puntajes de aptitud lingüística no garantiza que tengan menos éxito en el aprendizaje de idiomas.

Palabras clave: aptitud lingüística; aprendizaje de idiomas; nivel de logro.

\section{Résumé}

\section{Interface entre l'aptitude des niveaux d'apprentissage des langues d'enseignants d'un professeur}

Le but principal de cette recherche est d'étudier s'il existe une corrélation entre les aptitudes linguistiques des professeurs de langues en formation initiale et les niveaux d'anglais. L'échantillon de l'étude déterminé par la méthode d'échantillonnage stratifié comprend 72 professeurs de langues en début de carrière, choisis parmi les professeurs de langues en première, deuxième, troisième et quatrième années de Département d'enseignement des langues. Dans cette étude, les données ont été collectées via un «test d'aptitude verbale» modifié à partir du site de succès psychométrique. Dans ce programme, l'analyse du coefficient de corrélation de Spearman a été utilisée pour déterminer la corrélation entre les aptitudes linguistiques des enseignants en langues avant l'emploi et leurs niveaux de réussite en anglais. Les résultats ont montré qu'il existe une relation modérée entre les niveaux de réussite en anglais des enseignants de langues en formation initiale, leur capacité d'apprentissage 
par cœur et leur sensibilité grammaticale, mais qu'il existe une faible relation entre la capacité de codage phonétique et les aptitudes linguistiques. En outre, une légère corrélation entre la capacité d'apprentissage inductif des enseignants en langues avant leur formation et leur niveau de réussite est constatée. Dans l'ensemble, même si les dimensions du test d'aptitude linguistique indiquaient un certain degré de corrélation entre les composantes de l'aptitude linguistique et le niveau de réussite en anglais, les résultats globaux du test d'aptitude linguistique indiquaient qu'il existait une faible corrélation entre la formation linguistique initiale et la formation continue. aptitudes linguistiques et niveaux de réussite des enseignants. Cependant, le fait que les enseignants de langues avant le service aient de faibles scores d'aptitudes linguistiques ne garantit pas qu'ils auront moins de succès dans l'apprentissage des langues.

Mots-clés : aptitude linguistique ; apprentissage de la langue ; niveau de réussite. 
Kübra Askak- Feryal Cubukcu

\section{CóMO CITAR ESTE ARTÍCULO}

Askak, K., \& Cubukcu, F. (2020). A comparison between academic achievement and language aptitude among pre-service language teachers. Lenguaje, 48(1), 143-159. doi: 10.25100/lenguaje.v48i1.7395 


\section{INTRODUCTION}

\section{Individual Differences in Second Language Acquisition}

Learners are different in the way they learn a second language. They differ in the rate of acquisition and in their level of achievement and these differences determine the success or failure of learners in language learning (Li, 2015). Therefore, individual differences among learners seem to be an essential part of learning process and because of its importance, language learning process has emerged as its own field of study (Nitta, 2006). Ellis (2008) reported that "in earlier periods learners were viewed in absolute terms, as innately endowed with or lacking in language learning skills" (p. 525) because the primary concern was to predict which learners would be successful in language learning. However, "in more recent research learners are seen as having different kinds of abilities and predispositions" (p. 525) for language learning, so the reason why some learners were more successful than others in language learning has been a basis for the studies on learner differences.

There are many factors which create a difference among individual learners. They can be classified in three groups: affective, social and cognitive factors (Ellis, 2008). While the social factors include the effect of socio-economic environment on learning, the affective and the cognitive factors lie inside the learner and they include language aptitude, motivation, anxiety, learning style and personality (Nitta, 2006). According to Ellis and Shintani (2014), language aptitude had a more consistent correlation to language achievement than style and personality. Therefore, it is clear that language aptitude is strongly related to learners' outcomes in language learning (Dörnyei, 2010; Singleton, 2014).

\section{Language Aptitude}

In recent decades, language aptitude has attracted more and more attention because it has been found to be one of the most important factors in second language learning, so many researchers have tried to define language aptitude in the context of learning (Wen, Biedroń, \& Skehan, 2017). To illustrate; according to Carroll and Sapon (as cited in $\mathrm{Li}$, 2015) language aptitude refers to "a set of cognitive abilities that are 'predictive of how well, relative to other individuals, an individual can learn a foreign language in a given amount of time and under given conditions'"' (p. 386). It is obvious that language aptitude can predict learners' language achievement. Moreover, Robinson (2001) sees language aptitude as a cognitive ability to process information for language learning (Li, 2015). Language aptitude could make learning easier for pre-service language teachers through the use of cognitive strategies such as repetition, guessing meaning, organizing new language etc. All in all, it can be said that language aptitude is a special ability which is important for second or foreign language learning (Elmechta, 2016).

Language aptitude is an umbrella term which consists of four components proposed by John Carroll (Ellis, 2008). The first component is phonetic coding ability 
and Rysiewicz (2008) defined it as "the ability to segment and identify (code) distinct foreign sounds, to form associations between them and graphemic symbols representing them for later use" (p. 572). As can be understood from this definition it is necessary to code the sounds and match these sounds with their orthographic representations so that they can be used to speak the target language effectively (Moskovsky, Alshahrani, Ratcheva, \& Paolini, 2015). Through mental processes such as coding, assimilation and remembering, learners can learn second or foreign languages easily (Elmechta, 2016).

The second component is grammatical sensitivity which is defined by Robinson (as quoted in Piraud, 2008) as "the ability to recognize the grammatical functions of words (or other linguistic entities) within sentences" (p. 99). Broadly, the grammatical sensitivity refers to the awareness of syntactic patterns in sentences and different levels of grammatical sensitivity among pre-service language teachers can affect their language learning, to illustrate, the learners with high grammatical sensitivity recognize linguistic patterns easily and quickly (Piraud, 2008). Additionally, Carroll (1968) states that reading and writing require high level of grammatical sensitivity and learners have to work out grammatical analysis to learn a foreign language. Therefore, the grammatical sensitivity is an important aspect of language aptitude which enhances language learning.

The third component is inductive learning ability which enables learners to induce grammatical rules from language samples (Li, 2015). Through the inductive learning ability learners can become independent thinkers and they can take an active role in learning the forms and meanings of linguistic patterns (Herron \& Tomasello, 1992). Moreover, grammatical sensitivity and inductive language learning ability are higher skills which are strongly correlated with L2 success (Moskovsky et.al, 2015). Therefore, the inductive learning ability is one of the key aspects of language aptitude which makes the mappings between forms and meanings of linguistic features possible for learners (Carroll, 1968).

The fourth component of language aptitude is rote learning ability which is based on associative working memory (Cowan, 2014). Wen and Skehan (2011) views the working memory as "a combination of storage and manipulation" of information (p. 4) and second language acquisition is based on cognitive resources including working memory and in different stages of language learning which are input processes, central processing and output processing, the working memory facilitates noticing and processing the language patterns. Therefore, it is clear that working memory is an essential aspect of language aptitude because it helps learners keep information and use this information during the learning process (Ellis \& Sinclair, 1996). In short, the four components of language aptitude can be summarized in Table 1. 
Table 1. Carroll's Four-Factor Aptitude Model
Aptitude Components
Definitions of Abilities

Phonemic coding ability Capacity to code unfamiliar sound so that it can be retained.

Grammatical sensitivity

Inductive language learning ability

Associative memory
Capacity to identify the functions that words fulfill in sentences.

Capacity to extrapolate from given corpus to create new sentences.

Capacity to form links in memory.

As a result, language aptitude is a significant variable to examine pre-service language teachers' achievement in language learning because it includes different abilities which have a positive influence on pre-service language teachers' language learning process, so whether aptitude really plays a role in ultimate attainment is an important research interest (Grymska, 2016).

\section{Historical Overview of Language Aptitude}

The field of language aptitude has a long history and the research in this area started with the American educational psychologist John Carroll's study on the concept of foreign language aptitude in the 1950s (Rysiewicz, 2008). In his study, Carroll emphasized that individual learners have different capacities to learn foreign languages easily and speaking a foreign language requires a special talent which is the language aptitude (Wen et al., 2017). Moreover, Carroll and his colleague Sapon developed the Modern Language Aptitude Test (MLAT) battery in 1956 to measure individual learner's aptitude for a foreign language learning and this battery paved the way for subsequent aptitude measures such as The Pimsleur Language Aptitude Battery (PLAB), so it is seen as the most influential aptitude test in this field of study (Li, 2015).

After the publication of MLAT, research on language aptitude continued mainly in three different areas (Wen \& Skehan, 2011). One of them was about the development of aptitude tests, so alternative tests to MLAT such as Al-Haik's Defense Language Aptitude Battery (DLAB). Al Haik developed an alternative test called Defense Language Aptitude Battery (DLAB) to determine armed service members' ability in a foreign language (Wen et al., 2017). The other research area focused on the components of language aptitudes, additionally, the studies measuring the aptitude 
levels of learners and their relation with motivation and achievement exponentially increased because it was believed that they would provide pedagogical implications for L2 learning (Wen \& Skehan, 2011).

Starting from the 1970s, however, the research on language aptitude has slowed down because the concept of language aptitude was criticized for two reasons: for its origin associated with the outdated audio-lingual methodologies and for the low aptitude score which labels a language learner as an untalented person in learning a new language (Li, 2015). Nonetheless, in the course of time these two criticisms that aptitude was rooted in the audio-lingual method and that without aptitude, learners cannot acquire a language have been invalidated in many studies highlighting the role of memory (Archibald, 2017; Baddeley, 2012; Desmond \& Fiez, 1998) and the concept of language aptitude has gained momentum (Grymska, 2016).

\section{Achievement and Language Aptitude}

The correlation between learners' language aptitude and their achievement levels in English has been a research subject for many years. However, there are contradictory results in this research area because of the difficulty of determining learners' language aptitude which is a multi-component concept consisting of phonemic decoding, grammatical sensitivity, inductive association and memory (Wen et al., 2017). Even so, past studies give an implication for the present study of the correlation between learners' language aptitude and their English achievement level.

Some studies in this area show that there is a significant relation between preservice language teachers' language aptitude and their English achievement. To illustrate; Wang and Wu (2017) investigated the influence of language aptitude on EFL pre-service language teachers at Beijing University through Modern Language Aptitude Test (MLAT). The results showed that there was a correlation between language aptitude and English learning, so the pre-service language teachers who got high scores from MLAT were better especially in writing and reading skills (Wang \& $\mathrm{Wu}, 2017)$. Another study in a different context shows similar results. In this study, Moskovsky et al. (2015) conducted a research on first-year Saudi university preservice language teachers to examine the extent to which aptitude predicts second language achievement. Pre-service language teachers were given Aptitude and English proficiency tests. Pre-service language teachers with the high aptitude test scores were more successful than the ones with the low aptitude test scores especially in literacy skills (Moskovsky et al., 2015). Moreover, Elmechta (2016) investigated the impact of language aptitude and working memory on language learning achievement. The language aptitude measure and the working memory measure were given to preservice language teachers at Mentouri Brothers-Constantine University. Results showed that the university pre-service language teachers with higher working memory capacity were more successful in language learning. As a result, working memory and aptitude showed a significant association with achievement (Elmechta, 2016). 
There are also some studies which show that there is not a significant relation between language aptitude and achievement. For instance, the predictive validity of the Graduate Record Examinations (GRE) aptitude test has been investigated for foreign students at the University of Kansas by Kaiser (1983). A total of 148 students whose first language was other than English were selected for this study. Verbal and quantitative scores on the GRE, field of study, sex, and year of initial enrollment were used as predictors. The grade point average (GPA) in the graduate school was considered as the criterion. The results revealed that foreign students scored significantly lower than American students on the GRE scores. Poor correlation between the GRE scores and the criterion suggested that the GRE aptitude test is not the most appropriate way to predict academic performance of foreign students. Additionally, Goodman, Freed and McManus (1990) investigated the relation between university pre-service language teachers' language aptitude scores and their semester grades. At the University of Pennsylvania 586 pre-service language teachers were given Modern Language Aptitude Test (MLAT) and only a weak correlation between MLAT scores and pre-service language teachers' grades was found (Goodman et al., 1990).

Although some research findings point to a close relation between language aptitude and achievement, other studies do not show any relation of language aptitude with achievement. Therefore, uncertainty remains in this research area, so to provide a better insight into this area, two questions will be answered in the present study:

- What are the pre-service language teachers' language aptitude levels?

- Is there a correlation between pre-service language teachers' language aptitude and their English achievement levels?

\section{Methodology}

\section{Participants}

This study was conducted with 72 pre-service language teachers at English Language Teaching (ELT) department. Their ages varied between 18-20. The department they studied at offered four-year long courses on methodology, applied linguistics, sociolinguistics, research design, information technologies conducted in English. The participants were selected through the stratified sampling method. Since they were almost eligible to be qualified as English language teachers, their proficiency levels were $\mathrm{C} 1$. The reason why pre-service language teachers were selected as the study group was that their proficiency levels were higher than the average learners. Before coming to study at the English Language Teaching Department that they studied for four years, they had already passed two national tests given on English proficiency by the Higher Council of Education. 


\section{Instrument}

In this study, the purpose was to investigate the correlation between pre-service language teachers' language aptitude and their English achievement levels was investigated. Data were obtained through a verbal aptitude test which was modified from the psychometric success site of the university where the researchers worked. It was adapted and pilot-tested for the reliability, which was .78. The verbal aptitude test included 42 questions related to the four components of language aptitude, so the questions measure pre-service language teachers' phonemic coding ability, grammatical sensitivity, inductive language learning ability and rote learning ability. Some sample questions are listed below:

1. Find out the incorrect spelling
A) occurence
B) dissipate
C) weird
D) accommodate
E) embarrassment

2. Which of these is the missing word? water, -----------, over
A) ice
B) drive
C) wet
D) flow
E) fall

3. Which of these words is the odd one out?
A) swindle
B) harass
C) provoke
D) annoy
E) pester

Moreover, pre-service language teachers' grade point averages from all the English medium-based courses at school (GPAs) were obtained to find a correlation between pre-service language teachers' language aptitude and achievement levels.

\section{Procedure}

The verbal aptitude test was administered to pre-service language teachers during their Applied Linguistics Seminar class. All of the pre-service language teachers were informed about the aim of this study. Their consents forms were taken and they were asked to complete the verbal aptitude test. They were also asked to write their GPA (their grade point average for the department) English exam scores on the sheet. 


\section{Data Analysis}

The data were analyzed through Statistical Package for the Social Sciences (SPSS) program. In this program, the Spearman Product Moment Correlation Coefficient analysis was used to determine whether there is a correlation between pre-service language teachers' language aptitude and their English achievement levels.

\section{Data Results}

In the present study, the findings are discussed in relation to the two research questions:

- What are the university pre-service language teachers' language aptitude levels?

The mean and standard deviation values were calculated to elicit pre-service language teachers' language aptitude. According to the findings, the mean of the total aptitude scale is .35 which shows that pre-service language teachers have a low level of language aptitude.

- Is there a correlation between pre-service language teachers' language aptitude and their English achievement levels?

In the present study, the findings are discussed in relation to the four components of language aptitude test which are phonetic coding ability, grammatical sensitivity, inductive language learning ability and rote learning ability. The correlation of each component with pre-service language teachers' achievement levels is analyzed.

Firstly, when we look at the correlation between pre-service language teachers' phonetic coding ability and their English achievement levels, it is clear that there is a slight correlation $(r=.30)$ as shown in Table 2.

Table 2. The correlation between phonetic coding ability and achievement

\begin{tabular}{|c|c|c|c|}
\hline & & $\begin{array}{l}\text { Phonetic coding } \\
\text { ability }\end{array}$ & $\begin{array}{l}\text { English } \\
\text { achievement } \\
\text { scores }\end{array}$ \\
\hline \multirow{3}{*}{$\begin{array}{l}\text { Phonetic coding } \\
\text { ability }\end{array}$} & Spearman Correlation & 1 & .30 \\
\hline & Sig. (2-tailed) & & .02 \\
\hline & $\mathrm{N}$ & 72 & 72 \\
\hline \multirow{3}{*}{$\begin{array}{l}\text { English achievement } \\
\text { scores }\end{array}$} & Spearman Correlation & .30 & 1 \\
\hline & Sig. (2-tailed) & .02 & \\
\hline & $\mathrm{N}$ & 72 & 72 \\
\hline
\end{tabular}


Secondly, it was found that there is a moderate correlation $(r=.39)$ between pre-service language teachers' grammatical sensitivity and their L2 achievement as seen in Table 3.

Table 3. The correlation between grammatical sensitivity and achievement

\begin{tabular}{llcc}
\hline & & $\begin{array}{l}\text { English } \\
\text { achievement } \\
\text { scores }\end{array}$ & $\begin{array}{c}\text { Grammatical } \\
\text { sensitivity }\end{array}$ \\
\hline English & Spearman Correlation & 1 & .39 \\
achievement scores & Sig. (2-tailed) & & .04 \\
& $\mathrm{~N}$ & 72 & 72 \\
Grammatical & Spearman Correlation & .39 & 1 \\
sensitivity & Sig. (2-tailed) & .04 & 72 \\
& $\mathrm{~N}$ & 72 & \\
\hline
\end{tabular}

Thirdly, results showed that there is a moderate correlation $(r=.53)$ between pre-service language teachers' inductive language learning ability and their English achievement level as shown in Table 4.

Table 4. The correlation between inductive learning ability and achievement

\begin{tabular}{llcc}
\hline & & \multicolumn{2}{c}{$\begin{array}{c}\text { English } \\
\text { achievement } \\
\text { learning ability }\end{array}$} \\
& scores \\
\hline Inductive learning & Spearman Correlation & 1 & .53 \\
ability & Sig. (2-tailed) & & .07 \\
& $\mathrm{~N}$ & 72 & 72 \\
English achievement & Spearman Corelation & .53 & 1 \\
scores & Sig. (2-tailed) & .07 & 72 \\
& $\mathrm{~N}$ & 72 & \\
\hline
\end{tabular}

Therefore, in the view of such findings the ability of pre-service language teachers to learn the forms and meanings of linguistic patterns implies that they will get a high score in English tests.

Lastly, it was found that there is a weak correlation $(r=.23)$ between pre-service language teachers' rote learning ability and their English achievement level as shown in Table 5. 
Table 5. The correlation between rote learning ability and achievement level

\begin{tabular}{|c|c|c|c|}
\hline & & $\begin{array}{l}\text { Rote learning } \\
\text { ability }\end{array}$ & $\begin{array}{l}\text { English } \\
\text { achievement } \\
\text { scores }\end{array}$ \\
\hline \multirow{3}{*}{$\begin{array}{l}\text { Rote learning } \\
\text { ability }\end{array}$} & Spearman Correlation & 1 & .23 \\
\hline & Sig. (2-tailed) & & .05 \\
\hline & $\mathrm{N}$ & 72 & \\
\hline \multirow{3}{*}{\multicolumn{2}{|c|}{$\begin{array}{l}\text { English Spearman Correlation } \\
\text { achievement scores Sig. (2-tailed) } \\
\mathrm{N}\end{array}$}} & .23 & 1 \\
\hline & & .05 & \\
\hline & & 72 & 72 \\
\hline
\end{tabular}

According to the findings, pre-service language teachers' English scores are dependent on their ability to notice and process linguistic patterns during the learning process, so pre-service language teachers' rote language learning ability is a predictor of their success in English.

When we look at the overall correlation between pre-service language teachers' language aptitude and their English achievement levels, it is clear that there is a slight correlation (0.35) as shown in Table 6.

Table 6. Correlation between language aptitude and achievement

\begin{tabular}{llcc}
\hline & & $\begin{array}{l}\text { English } \\
\text { achievement level }\end{array}$ & $\begin{array}{c}\text { Language aptitude } \\
\text { test scores }\end{array}$ \\
\hline English & Spearman Correlation & 1 & .35 \\
achievement & Sig. (2-tailed) & 72 & .01 \\
level & $\mathrm{N}$ & .35 & 72 \\
Language & Spearman Correlation & .01 & 1 \\
aptitude test & Sig. (2-tailed) & 72 & 72 \\
scores & $\mathrm{N}$ & & \\
\hline
\end{tabular}

It can be said that there is not a strong linear relationship of language aptitude with pre-service language teachers' achievement levels, so aptitude test is not an appropriate way to predict English achievement of the pre-service language teachers. Moreover, there can be other mediating factors such as motivation, anxiety and selfregulation which affect the correlation between pre-service language teachers' language aptitude and their English achievement levels.

\section{Discussion}

The present study was conducted to investigate the pre-service language teachers' language aptitudes and whether there is a correlation between pre-service language teachers' language aptitude and their English achievement levels. The data which were collected from 72 pre-service language teachers via a verbal aptitude test were analyzed through Spearman Product Moment Correlation Coefficient analysis. 
Generally, it was found that pre-service language teachers' language aptitude scores are low.

Moreover, the findings were examined in terms of four dimensions of the verbal test. Results showed that while there is a weak relation of pre-service language teachers' English achievement levels with their rote learning ability (.23), phonetic coding ability (.30) and grammatical sensitivity (.39). The highest correlation is between inductive learning and achievement (.53), which is considered as moderate. In the related literature, it is possible to find similar results. Bernad (2015) states that there is only a weak correlation between students' scores and their phonetic coding ability. Additionally, a moderate correlation between pre-service language teachers' inductive learning ability and their achievement levels (.53) is in line with the earlier studies. To illustrate, Moskovsky et al. (2015) reports that there is a strong correlation between students' English proficiency scores and their inductive learning ability.

Even if the dimensions of language aptitude test points to some degree of correlation between the components of language aptitude and English achievement level, the overall results of the language aptitude test indicate that there is a weak correlation between pre-service language teachers' language aptitude and achievement levels. Similarly, Kaiser (1983) states that there is a poor correlation between pre-service language teachers' aptitude scores and their GPA scores, so aptitude is not an effective predictor of L2 success. Additionally, Goodman et.al. (1990) report that there is little relationship between pre-service language teachers' MLAT scores and their grades in language classes.

To conclude, depending on the findings of this study, there is not a linear correlation between students' language aptitude and their English achievement levels. This may be due to other mediating factors such as motivation, anxiety and selfregulation. In a similar manner, Bernad (2015) reports that language aptitude does not have an influence on students' test scores because of students' motivation, learning strategies and anxiety. It is clear that language aptitude is not the only factor which determines students' language achievement.

\section{CONCLUSIONS}

In the present study firstly pre-service language teachers' language aptitude scores were investigated and it was found that pre-service language teachers have got relatively low scores on the language aptitude test. Secondly, the correlation between two variables, which are pre-service language teachers' language aptitude and their English test scores, was determined through Spearman Correlation Coefficient. The findings of the study revealed that overall there is a slight correlation between learners' language aptitude and their English achievement scores. Therefore, the fact that pre-service language teachers have low language aptitude scores does not guarantee they will be less successful in language learning. Hence, there are some recommendations based on the results of present research. Firstly, in the educational practices, the affective, cognitive and social individual variables should be taken into 
consideration. Secondly, teachers should be aware of that students' language achievement is determined by many factors rather than only language aptitude.

\section{REFERENCES}

Archibald, L. (2017). Working memory and language learning: A review. Child Language Teaching and Therapy, 33(1) 5-17. doi: 10.1177/0265659016654206.

Baddeley, A. (2012). Working Memory: Theories, Models, and Controversies. Annual Review of Psychology, 63, 1-29. doi: 10.1146/annurev-psych-120710-100422.

Bernad, M. (2015). The Role of Aptitude in FLL (Foreign Language Learning) at University (Bachelor's Thesis). Retrieved from https://dd.uab.cat/record/137418.

Carroll, J. B. (1968). Psychological Considerations in Setting Aims for Foreign Language Teaching. Paper presented at the Seminaire International sur la Differenciation Structural entre les buts de Penseignement des langues sur les Divers Plans du Systeme Scolaire, Prague, Czechoslovakia. Retrieved from https://files.eric.ed.gov/fulltext/ED031107.pdf.

Cowan, N. (2014). Working Memory Underpins Cognitive Development, Learning, and Education. Educational Psychology Review, 26(2), 197-223. doi: 10.1007/s10648013-9246-y.

Desmond, J., \& Fiez, J. (1998). Neuroimaging studies of the cerebellum: language, learning and memory. Trends in Cognitive Sciences, 2(9), 355-362. doi: 10.1016/S1364-6613(98)01211-X.

Dörnyei, Z. (2010). The relationship between language aptitude and language learning motivation: Individual differences from a dynamic systems perspective. In E. Macaro (Ed.), The Continuum Companion to Second Language Acquisition (pp. 247-267). London: Continuum.

Ellis, R. (2008). The Study of Second Language Acquisition (2nd ed.). Oxford: Oxford Universtity Press.

Ellis, N. C., \& Sinclair, S. G. (1996). Working Memory in the Acquisition of Vocabulary and Syntax: Putting Language in Good Order. The Quarterly Journal of Experimental Psychology, 49A(1), 234-250. doi: 10.1080/713755604.

Ellis, R., \& Shintani, N. (2014). Catering for learner differences through instruction. In Exploring Language Pedagogy through Second Language Acquisition Research (pp. 285-317). New York: Routledge.

Elmechta, L. (2016). The Impact of Language Aptitude, Working Memory and Verbal Reasoning as Aspects of Linguistic Intelligence on Language Learning Achievement (Master's thesis). Retrieved from https://bu.umc.edu.dz/theses/anglais/ELM1425.pdf.

Goodman, J. F., Freed, B., \& McManus, W. J. (1990). Determining exemptions from foreign language requirements: Use of the Modern Language Aptitude Test. Contemporary Educational Psychology, 15(2), 131-141. doi: 10.1016/0361-476X(90)90012-P.

Grymska, B. (2016). New Conceptualizations of Language Aptitude-The Potential of 
Working Memory in Second Language Acquisition (SLA). Theory and Practice of Second Language Acquisition, 2 (1), 103-118. Retrieved from http://www.journals.us.edu.pl/index.php/TAPSLA/article/view/3947.

Herron, C., \& Tomasello, M. (1992). Acquiring Grammatical Structures by Guided Induction. The French Review, 65(5), 708-718. Retrieved from http://www.jstor.org/stable/395311.

Kaiser, J. (1983, February). The Differential Predictive Validity of the GRE Aptitude Test for Foreign Students. Paper presented at the Annual Meeting of the Eastern Educational Research Association, Baltimore, MD. Retrieved from https://files.eric.ed.gov/fulltext/ED227174.pdf.

Li, S. (2015). The Associations Between Language Aptitude and Second Language Grammar Acquisition: A Meta-Analytic Review of Five Decades of Research. Applied Linguistics, 36(3), 385-408. doi: 10.1093/applin/amu054.

Moskovsky, C., Alshahrani, M., Ratcheva, S., \& Paolini, S. (2015). Aptitude as a Predictor of Second Language Achievement: An Investigation in the Saudi Arabian Context. Arab World English Journal, 6(1), 3-21. doi: 10.2139/ssrn.2834408.

Nitta, T. (2006). Affective, Cognitive and Social factors affecting Japanese learners of English in Cape Town (Master's thesis). Retrieved from https://core.ac.uk/download/pdf/58913168.pdf.

Piraud, M. (2008). Grammatical sensitivity: a correlational-explanatory study on brain dominance and EFL training to improve gains. Colombian Applied Linguistics Journal, (10), 93-111. doi: 10.14483/22487085.99.

Robinson, P. (2001). Individual differences, cognitive abilities, aptitude complexes and learning conditions in second language acquisition. Second Language Research, 17(4), 368-392. doi: 10.1177/026765830101700405.

Rysiewicz, J. (2008). Measuring Foreign Language Learning Aptitude. Polish Adaptation of The Modern Language Aptitude Test By Carroll and Sapon. Poznań Studies in Contemporary Linguistics, 44(4), 569-595. doi: 10.2478/v10010008-0027-6.

Singleton, D. (2014). Apt to change: The problematic of language awareness and language aptitude in age-related research. Studies in Second Language Learning and Teaching, 4(3), 557-571. doi: 10.14746/ssllt.2014.4.3.9.

Wang, K., \& Wu, J. (2017). The Influence of Language Aptitude on EFL Learners in SLA. Higher Education of Social Science, 12(2), 1-10. doi: 10.3968/9754.

Wen, Z., \& Skehan, P. (2011). A new perspective on foreign language aptitude research: Building and supporting a case for "working memory as language aptitude". Ilha do Desterro, (60), 15-43. doi: 10.5007/2175-8026.2011n60p015.

Wen, Z., Biedroń, A., \& Skehan, P. (2017). Foreign language aptitude theory: Yesterday, today and tomorrow. Language Teaching, 50(1), 1-31. doi: $10.1017 /$ S0261444816000276. 


\section{SOBRE LAS AUTORAS}

\section{Kübra Aksak}

Se graduó del Departamento de Enseñanza del Idioma Inglés de la Universidad Dokuz Eylül. Actualmente es estudiante de maestría en el Departamento de ELT en la misma universidad. Trabaja como maestra de inglés en una escuela primaria. Sus principales intereses son la lingüística aplicada y los estilos de aprendizaje.

Correo electrónico: k.aksak@hotmail.com

Orcid: 0000-0001-5106-4686.

\section{Feryal Cubukcu}

Es profesional y magíster en Educación y doctora en Teorías Literarias. Sus principales intereses son los estudios culturales, la psicolingüística, la lingüística aplicada y los estudios cinematográficos. Actualmente trabaja como directora del Departamento de Enseñanza del Idioma Inglés de la Universidad Dokuz Eylül.

Correo electrónico: cubukcu.feryal@gmail.com

Orcid: 0000-0003-3313-6011. 